\title{
Expression of the Cholecystokinin-B Receptor in Neoplastic Gastric Cells
}

\author{
Patricia Mjønes ${ }^{1,2,3}$ • Ivar S. Nordrum ${ }^{2,3}$ • Øystein Sørdal ${ }^{1,4}$ • Liv Sagatun ${ }^{1,4}$. \\ Reidar Fossmark $^{1,4}$ • Arne Sandvik ${ }^{1,4}$ • Helge L. Waldum ${ }^{1,4}$
}

Received: 20 July 2017 / Accepted: 25 September 2017 /Published online: 4 October 2017

(C) The Author(s) 2017. This article is an open access publication

\begin{abstract}
Gastric cancer is an important disease due to its high mortality. Despite the decline in frequency, most cases are discovered late in its course, and most of the cancer patients die within a few years of diagnosis. In addition to Helicobacter pylori gastritis, gastrin is considered an important factor in the development of this disease, and thus, cholecystokinin-B receptor (CCKBR) becomes of interest. The aim of our study was to explore whether CCKBR is expressed in stomach cancers. Thirty-seven tumors from 19 men and 18 women diagnosed with either adenocarcinoma or neuroendocrine neoplasm (NENs) were included in this study. The tumors were classified into 29 adenocarcinomas and eight NENs. Immunohistochemistry with antibodies against chromogranin A (CgA), synaptophysin and CCKBR, and in situ hybridization with probes against $\mathrm{CgA}, \mathrm{CCKBR}$ and histidine decarboxylase were used to further explore these tumors. Thirty-three (89\%) of the tumors expressed CCKBR protein, whereas only $20(54 \%)$ of all tumors expressed CCKBR mRNA. Of the 20 tumors expressing CCKBR mRNA, eight were NENs and 12 were adenocarcinoma. The
\end{abstract}

Patricia Mjønes

Patricia.mjones@ntnu.no

Ivar S. Nordrum

ivar.nordrum@ntnu.no

Øystein Sørdal

osordal@rcsi.ie

Liv Sagatun

liv.sagatun@stolav.no

Reidar Fossmark

reidar.fossmark@ntnu.no

Arne Sandvik

arne.sandvik@ntnu.no highest amount of CCKBR was expressed in NEN. Interestingly, a high degree of co-expression of CCKBR and $\mathrm{CgA}$ was observed when the two markers were examined together with in situ hybridization. In conclusion, we found that all eight NENs expressed CCKBR and neuroendocrine markers in a majority of tumor cells. The same markers were also expressed in a proportion of adenocarcinomas supporting the view that gastrin is important in the development of gastric cancer.

Keywords Gastrin receptor - Cholecystokinin-2 receptor . CCK2R - Cholecystokinin-B receptor · CCKBR .

Neuroendocrine

\section{Introduction}

Gastric cancer is one of the leading causes of cancer deaths worldwide and is ranked as the fifth most common malignancy [1]. Despite the decline in prevalence over the last decades,

Helge L. Waldum

helge.waldum@ntnu.no

1 Department of Cancer Research and Molecular Medicine, Faculty of Medicine and Health Sciences, Norwegian University of Science and Technology, Trondheim, Norway

2 Department of Pathology, St Olav's Hospital—Trondheim University Hospital, Trondheim, Norway

3 Department of Laboratory Medicine, Children's and Woman's Health, NTNU, Trondheim, Norway

4 Department of Gastroenterology and Hepatology, St Olav's Hospital-Trondheim University Hospital, Trondheim, Norway 
most cases are discovered at an advanced stage, and subsequently most of the cancer patients die within a few years of diagnosis. There are many ways of classifying gastric cancer, but Lauréns classification into diffuse, intestinal and indeterminate/mixed types is commonly applied. The various subtypes do not appear to transform into other, suggesting important biological discrepancies between the two $[2,3]$. In addition, the intestinal type continues to decline in incidence, whereas the incidence of the diffuse type remains constant across the various populations, supporting this view [3].

A certain number of gastric carcinomas express neuroendocrine (NE) markers $[4,5]$. A few studies even suggest that gastric carcinomas of the diffuse type originate from enterochromaffin-like (ECL) cells by dedifferentiation $[6,7]$. Co-occurrence of neuroendocrine tumors (NETs) and gastric carcinomas in patients with chronic atrophic gastritis (CAG) is also an indication of a close relationship between the two entities [8]. A number of gastric carcinomas of the intestinal type also express NE markers, but not as commonly as with the diffuse type. In some patients with gastric carcinoma, there are elevated gastrin levels $[9,10]$, incriminating gastrin as a driving force in the development of these cancers.

There are three types of neuroendocrine tumors (NETs) in the stomach. Type 1 is the most common accounting for approximately $80 \%$ of cases and is associated with CAG [11, 12]. ECL cells of the gastric mucosa are known to express cholecystokinin-B receptors (CCKBR), also known as gastrin receptor or cholecystokinin-2 receptors (CCK2R) [13]. Originating from ECL cells, NET type 1 is thought to express CCKBR. Studies done on patients with CAG and NETs treated with the CCKBR antagonist netazepide, have shown promising results in terms of decrease in tumor size and in some patients complete remission $[14,15]$. The effect of gastrin is mediated by the binding of gastrin to its receptor CCKBR. CCKBR is a seven-transmembrane $G$ protein-coupled receptor expressed in the proximal two thirds of the stomach [16]. The presence of CCKBR on the ECL cell and its role in acid secretion is undisputed [17], but there is controversy with regard to the expression of this receptor on the parietal and other cells.

Even though the incidence of stomach cancer is decreasing, it is still an important disease due to its high mortality. The reduced occurrence of stomach cancer has mainly affected adenocarcinoma of the intestinal type, the incidence of the diffuse type remaining largely unchanged $[18,19]$. The association between Helicobacter pylori infection and gastric adenocarcinoma is well established [20], and thus, the reduction in adenocarcinoma of the intestinal type is partly explained by eradication of the bacterium as well as reduced incidence of Helicobacter pylori infection. Hypoacidity and hypergastrinemia are also factors associated with increased risk of both gastric NETs and adenocarcinomas [21, 22]. These factors together with the fact that a proportion of gastric carcinomas display markers of NE and ECL cell differentiation, suggestive of ECL cell origin, result in gastrin becoming of interest in gastric carcinogenesis. We wished to explore this further by examining the expression of CCKBR in gastric cancer, including neuroendocrine neoplasms (NENs) and gastric carcinomas of the diffuse and intestinal types. Our hypothesis was that CCKBR is expressed in ECL cell hyperplasias and NENs, and we wanted to see if the same was the case for adenocarcinomas. By assessing whether the cancer cells express CCKBR or not, one can determine which patients may experience benefits from treatment with a CCKBR antagonist.

\section{Materials and Methods}

\section{Patients}

Thirty-seven tumors from 37 different patients who were either treated with a total or subtotal gastrectomy or who had their tumor removed via endoscopy at St. Olavs HospitalTrondheim University Hospital between 1995 and 2016 were included in the study. The patients were identified from previous studies [7] and by going through our records at the pathology and gastroenterology departments. All the patients were either diagnosed with adenocarcinoma or NEN. Archival formalin-fixed, paraffin-embedded (FFPE) tissue was reexamined and further subdivided into adenocarcinoma of intestinal or diffuse type according to Laurén [2], or neuroendocrine tumor (NET) grade 1 or 2, or neuroendocrine carcinoma (NEC) according to the WHO classification from 2010 [23]. American Joint Committee on Cancer (AJCC), Cancer Staging Manual, eight edition was used in order to stage the tumor [24]. Tumor size was when available noted and was defined as the area with greatest diameter recorded in the pathology specimen.

Immunohistochemical (IHC) stainings with antibodies against $\mathrm{CCKBR}$, chromogranin $\mathrm{A}(\mathrm{CgA})$ and synaptophysin were performed, and in situ hybridization (ISH) with probes against CCKBR, histidine decarboxylase (HDC) and CgA was also carried out. By conducting these studies, we wished to find out whether all carcinomas of the human stomach express CCKBR and also whether all cells expressing CCKBR are positive for one or more NE markers.

\section{Histopathology and Immunohistochemistry}

IHC was performed as described previously with a few minor modifications [25]. For this study, the following antibodies were used: chromogranin A (M0869, Dako, Glostrup, Denmark, 1:200), Synaptophysin (M7315, Dako, 1:200), CCKBR (PA5-33389, Thermo Fischer Scientific, Rockford, USA, 1:250), Pepsinogen II (Ab9013-1; Abcam, Cambridge, UK, 1:1000), and HKATPase (MA3-923; Affinity 
Bioreagents, Golden, CO, USA, 1:1500). Mouse Link (K8021, Dako) was used with the monoclonal mouse antibodies ( $\mathrm{CgA}$ and synaptophysin) to further amplify the signal. $\mathrm{CgA}$, synaptophysin, CCKBR, and HKATPase were visualized by using an EnVision-HRP kit with DAB+ (K5007, Dako). The sections were incubated with EnVision for 30 min. Pepsinogen II was visualized using a biotinylated secondary antibody for $30 \mathrm{~min}$ (Biotinylated anti-sheep IgG $(\mathrm{H}+\mathrm{L})$, Vector Laboratories, Burlingame, USA, 1:150), followed by application of "Vectastain ABC kit" (Vector Laboratories) for $30 \mathrm{~min}$. All sections were developed using $\mathrm{DAB}+$, before counterstaining with Mayer's haematoxylin (Sigma Life Science, Saint Louis, USA) for $10 \mathrm{~s}$. Mouse IgG2b (X0944, Dako) was used as a negative isotype control for CgA, mouse IgG1 (X0931, Dako) was used for synaptophysin, and diluent was used as a negative control for CCKBR. Tris/EDTA ( $\mathrm{pH}$ 9) was used as epitope retrieval solution for CCKBR, $\mathrm{CgA}$ and synaptophysin, and citrate buffer (pH 6) for Pepsinogen II and HKATPase. Between all steps after incubation with primary antibody a wash buffer solution was used to wash the sections. A TNT wash buffer (based on $0.1 \mathrm{M}$ Trizma hydrochloride, $0.15 \mathrm{M} \mathrm{NaCl}$ and $0.05 \%$ Tween 20 (VWR, Briare, France), pH 7.5) was used on sections incubated with CCKBR, CgA and synaptophysin, and PBS-TrX wash buffer solution (consisting of phosphatebuffered saline and $0.25 \%$ Triton-X-100 (VWR, Briare, France)) was used for sections incubated with pepsinogen II and HKATPase. A known NET of the stomach was used as positive control tissue for CgA, synaptophysin and CCKBR. The surrounding connective tissue and smooth muscle tissue were used as a negative control.

\section{In Situ Hybridization}

In situ hybridization (ISH) was done on all the tissue examined in this study by using either a single ISH assay or duplex ISH assay. In the single assay, a probe against CCKBR was used, and in the duplex assay probes against CCKBR, CgA and HDC were used. ISH with duplex ISH assay using probes against CCKBR and $\mathrm{CgA}$ was performed on all 37 tumors, whereas probes against CCKBR and HDC were used on only 23 tumors, due to lack of HDC probe for all 37 sections. A single ISH assay using a probe against CCKBR was used in order to ensure that the positive results found when using the ISH duplex assay were true, and not due to interference from the second probe.

For ISH RNAscope 2.5 HD Assay-Brown and RNAscope 2.5 HD duplex assay were used. The method was executed according to the protocols provided by Advanced Cells Diagnostics (ACD) with a few modifications. All steps till incubation of the probes were similar in the single and duplex assays. For both assays, $4-\mu \mathrm{m}$ thick sections were cut from tissue blocks of paraffin and transferred to SuperFrost Plus slides. After drying the slides at room temperature overnight, they were the following day placed in a heat cabinet at $60^{\circ} \mathrm{C}$ for $60 \mathrm{~min}$, before being deparaffinized in NeoClear for $2 \times 10$ min followed by dehydration in $100 \% \mathrm{EtOH}$ (absolute alcohol) for $2 \times 2 \mathrm{~min}$. The sections were then dried for $5 \mathrm{~min}$ before being incubated with hydrogen peroxide for $10 \mathrm{~min}$ at room temperature. The sections were thereafter immersed in boiling Target Retrieval (for RNA retrieval) for $15 \mathrm{~min}$, before being cooled in distilled water (30 s), followed by immersion of slides in fresh $100 \% \mathrm{EtOH}$. After air-drying the sections for $5 \mathrm{~min}$, an Immedge TM hydrophobic barrier pen was used to draw a barrier around the tissue, followed by incubation with Protease Plus (for protein digestion) for $15 \mathrm{~min}$ at $40{ }^{\circ} \mathrm{C}$. After this step, the sections were rinsed in distilled water before being incubated with the various probes for $2 \mathrm{~h}$ at $40^{\circ} \mathrm{C}$. For the RNAscope $2.5 \mathrm{HD}$ Assay-Brown single assay target probe against human CCKBR (Probe-Hs-CCKBR, catalog number: 31101 , ACD, USA), positive control probe (positive control probe-Hs-PPIB, catalog number: 313901, ACD, USA) and negative control probe (negative control probe-DapB, catalog number: 310043 , ACD, USA) were used. For RNAscope $2.5 \mathrm{HD}$ duplex assay target probes against human CCKBR (Probe-Hs-CCKBR-C2, catalog number: 31101C2, ACD), CgA (Probe-Hs-CHGA, catalog number: 31111, ACD) and HDC (Probe-Hs-HDC, catalog number: 311441, ACD) were used. Positive control probe (Duplex positive control probe-Hs-PPIB-C1/POLR2A-C2, catalog number: 321641, ACD, USA) and negative control probes (2-plex negative control probe, catalog number: 320751 , ACD, USA) for the duplex kit were also used. The sections going through RNAscope 2.5 HD single Assay-Brown were incubated with only a probe against CCKBR for $2 \mathrm{~h}$, whereas the sections being processed with RNAscope $2.5 \mathrm{HD}$ duplex assay, were incubated with a solution consisting of one part CCKBR probe in the $\mathrm{C} 2$ channel to 50 parts of either $\mathrm{CgA}$ or $\mathrm{HDC}$ in the $\mathrm{C} 1$ channel, also for $2 \mathrm{~h}$. After incubation, the sections were rinsed in a wash buffer solution following the kit, and signal amplification was done according to recommendations from $\mathrm{ACD}$.

The tissue sections incubated with only one probe (CCKBR) were then incubated with Amp 1 (preamplifier) for $30 \mathrm{~min}$ at $40{ }^{\circ} \mathrm{C}$, Amp 2 (background reducer) for 15 min at $40{ }^{\circ} \mathrm{C}$, Amp 3 (amplifier) at $40{ }^{\circ} \mathrm{C}$, Amp 4 (label probe) for $15 \mathrm{~min}$ at $40{ }^{\circ} \mathrm{C}$, Amp 5 for $30 \mathrm{~min}$ at room temperature, and finally, Amp 6 for $15 \mathrm{~min}$ at room temperature. After each of the steps, the sections were rinsed in wash buffer. For signal detection a DAB mixture (following the kit) was used, and counterstaining was done by staining the sections with hematoxylin and mounted using glycerel (glycergel mounting medium, DAKO).

Tissue sections incubated with two different probes (either CCKBR and $\mathrm{CgA}$, or CCKBR and HDC), were subsequently incubated with Amp 1 for $30 \mathrm{~min}$ at $40^{\circ} \mathrm{C}$, Amp 2 for $15 \mathrm{~min}$ at $40{ }^{\circ} \mathrm{C}$, Amp 3 for $30 \mathrm{~min}$ at $40{ }^{\circ} \mathrm{C}$, Amp 8 for $15 \mathrm{~min}$ at $40{ }^{\circ} \mathrm{C}$, Amp 5 for $30 \mathrm{~min}$ at room temperature, Amp 6 for 
$15 \mathrm{~min}$ at room temperature, followed by signal detection giving a red signal (following the kit). The probes in the $\mathrm{C} 1$ channel (CgA or HDC) stained red. After signal detection, the sections were further incubated with Amp 7 for $15 \mathrm{~min}$ at $40{ }^{\circ} \mathrm{C}$, Amp 4 for $30 \mathrm{~min}$ at $40^{\circ} \mathrm{C}$, Amp 9 for $30 \mathrm{~min}$ at room temperature, and finally Amp 10 for $15 \mathrm{~min}$ at room temperature. For signal detection, a mixture following the kit was used, giving the probe in the $\mathrm{C} 2$ channel (CCKBR) a green/ blue signal. The sections were counterstained by using $50 \%$ Mayer's hematoxylin, and mounted using VectaMount (catalog number: H-5000, Vector Laboratories).

RNA quality and background signals were evaluated by using positive and negative control probes, and positive staining was defined by the presence of dot like cytoplasmatic and/or nuclear staining that was stronger than the negative control (dapB). A known NET of the stomach was used as positive control. NE cells were used as positive internal controls for all the probes, and the surrounding connective and smooth muscle tissue was used as a negative internal control. In addition, a small biopsy from normal colonic mucosa was used as a negative control.

\section{Scoring and Reporting}

All sections were assessed by using a bright field microscope (Olympus CX41). IHC and ISH markers were assessed by one researcher, and when there were uncertainties with regard to results, a second pathologist/researcher was consulted. The quality of the staining was also accessed by a second researcher. As recommended by ACD, a semi-quantitative scoring approach to evaluate staining results was applied for both IHC and ISH.

\section{Classification of Tumors}

The tumors were reclassified according to the WHO classification from 2010 [23] and Laurén [2]. According to Laurén, the intestinal type is characterized by the presence of gland like structures, the diffuse type by poorly cohesive cells with no or minor gland formation, the mixed type by almost equal amounts of intestinal and diffuse types, and finally indeterminate type by undifferentiated tumor. In the present study, mixed and indeterminate types are described together. The NENs are subdivided into NETs grade 1 or 2 , or neuroendocrine carcinoma (grade 3 ) depending on the proliferative index of these tumors.

\section{Classification of Markers}

Reporting recommendations for tumor marker prognostic studies (REMARK) with a few modifications were followed [26]. The staining was classified as either positive or negative, and if appropriate the staining intensity (weak, moderate or strong) and number of tumor cells staining positive was also noted. Less than $2 \%$ positive cells was considered a negative or very low expression, 2-10\% positive cells was low, 10$40 \%$ positive cells was medium, $40-70 \%$ was high, and more than $70 \%$ positive cells was considered a very high expression. The staining pattern for the immunohistochemical markers CCKBR and CgA was further validated by using in situ hybridization technique.

\section{Statistical Analysis}

For calculation of median and mean values as well as range for the different parameters, IBM SPSS statistics version 22 (Chicago, IL, USA) was used. The descriptive data are presented as median or mean as appropriate. In order to look for association between the various variables, Spearman's nonparametric test was used.

\section{Ethical Approval}

The Regional Committee for Medical and Health Sciences Research Ethics (reference number in REK: 2016/1608) approved the study. For this study, no formal consent was required.

\section{Results}

\section{Patient Characteristics}

Of the 37 patients included in the study, 19 (51\%) were male and $18(49 \%)$ female. Their median age at time of diagnosis was 67 (range 32-79) years. At follow-up, 30 patients had died from their stomach cancer, and seven patients were still being followed-up according to current guidelines. Of the patients still alive five were diagnosed with NETs, the remaining two with adenocarcinoma of diffuse and intestinal type.

\section{Tumor Characteristics}

Fifteen $(41 \%)$ tumors were adenocarcinoma of diffuse type, ten $(27 \%)$ of intestinal type, four $(11 \%)$ were a mixture of the above (or indeterminate type), and eight (22\%) were NENs. Of the NENs, four were NET grade 1, two were NET grade 2, and two were NECs (grade 3). Twelve tumors (32\%) were located in the cardia/fundus area, $18(49 \%)$ in the corpus, and seven (19\%) in the antrum. Of the adenocarcinomas located to oxyntic mucosa (fundus and corpus) seven of 22 (32\%) were intestinal type, $11(50 \%)$ diffuse type, and four (18\%) mixed/indeterminate type. Of the antral adenocarcinomas, three of seven $(43 \%)$ were of the intestinal type and four $(57 \%)$ of the diffuse type. Tumor size was defined as the greatest diameter recorded in the pathology specimen, and the mean tumor size among the 37 tumors was 57 (range 2-240) $\mathrm{mm}$ with a SD of $48 \mathrm{~mm}$. When subdivided into the two 
subgroups adenocarcinoma and NEN, mean tumor size was as follows: adenocarcinoma of diffuse, intestinal type or mixed/ indeterminate type: 67 (range 11-240) $\mathrm{mm}$ with a SD of $49 \mathrm{~mm}$, and for NENs: 21 (range 2-75) mm, with a SD of $24 \mathrm{~mm}$. In accordance with American Joint Committee on Cancer (AJCC), Cancer Staging Manual, eight edition one (3\%) out of 29 adenocarcinomas was in the Tis category, one $(3 \%)$ was $\mathrm{T} 1$, one $(3 \%)$ was $\mathrm{T} 2,22(76 \%)$ were $\mathrm{T} 3$ and four $(14 \%)$ were T4. Of the NENs, three of eight $(38 \%)$ tumors were in the T1 category, three (38\%) T2 and two $(25 \%)$ T4. As an incidental finding, a gastrointestinal stromal tumor (GIST) was found in the stomach wall of case 26.

\section{Immunohistochemistry}

All 37 tumors were examined with antibodies against $\mathrm{CgA}$, synaptophysin, and CCKBR. The staining of $\mathrm{CgA}$ was cytoplasmatic, and the staining intensity was either strong or non-existent. Synaptophysin was expressed in the cytoplasm of the positive cells, and the staining intensity of synaptophysin was strong in the NETs, and weaker in the NECs and adenocarcinomas. The staining of CCKBR was mainly cytoplasmatic, and the staining intensity mainly moderate for NENs, and weak to moderate in the adenocarcinomas. The largest number of CCKBR expressing tumor cells was seen among the NENs. In addition to staining tumor cells and scattered NE cells, weak and possible non-specific binding was seen in luminal epithelial cells, fibroblast-like stromal cells, and endothelial cells.

\section{Neuroendocrine Neoplasms}

As NENs are known to express NE markers and CCKBR, these are considered a gold standard and described separately from the adenocarcinomas. All eight (100\%) NENs expressed $\mathrm{CgA}$ and synaptophysin, and seven (88\%) expressed CCKBR. The one case negative for CCKBR was NEC. The staining intensity was strong for the NE markers and moderate for CCKBR.

\section{Adenocarcinomas (Intestinal, Diffuse, and Mixed/Indeterminate Types)}

Eight of 29 (28\%) adenocarcinomas expressed CgA. This marker was observed in one of ten (10\%) intestinal type adenocarcinoma, five of $15(33 \%)$ diffuse type adenocarcinoma, and two of four (50\%) mixed/indeterminate type. Expression of synaptophysin was observed in nine of 29 (31\%) adenocarcinomas, and of these the marker was expressed in three of ten $(30 \%)$ intestinal type adenocarcinomas, four of $15(27 \%)$ diffuse type adenocarcinomas, and two of four (50\%) mixed/ indeterminate type adenocarcinomas. CCKBR was expressed in 26 of $29(90 \%)$ adenocarcinomas, where positive cases were observed in nine of ten $(90 \%)$ intestinal type adenocarcinomas, 14 of $15(93 \%)$ diffuse type adenocarcinoma, and three of four $(75 \%)$ mixed/indeterminate type adenocarcinomas. Table 1 gives an overview of staining results including approximately how many cells are positive for the various antibodies in each case.

\section{Gastric Mucosa}

In some of the tumor-containing sections, gastric mucosa was also visualized. The morphology ranged from normal gastric mucosa to CAG with varying degrees of ECL cell hyperplasia. In the mucosa with changes consistent with $\mathrm{CAG}$, CCKBR expression was only observed in ECL cells. In two separate biopsies, one from a patient with normal gastric mucosa and one from a patient with Zollinger-Ellison syndrome, CCKBR were observed in most cells below the isthmus area of the glands. The expression of CCKBR was strongest in the NE cells. HE stained sections and further examination with HKATPase and pepsinogen II demonstrated parietal cells and chief cells to be among the cells found in the same location.

\section{In Situ Hybridization}

ISH with a duplex ISH assay using a probe against CCKBR and $\mathrm{CgA}$ was performed on all 37 tumors, whereas a probe against CCKBR and HDC was used on only 23 tumors. CCKBR mRNA stained green/blue and CgA mRNA and HDC mRNA stained red. The sections were viewed in a bright field microscope, and proportion of cells expressing green/ blue and red signals was noted. For all probes used, the staining intensity/number of dot-like structures seen in each cell was higher in NENs compared with carcinomas. HDC was in addition to staining tumor cells positive in some stromal cells, which were thought to represent mast cells.

Interestingly, in ECL cell hyperplasia and NETs there was co-expression of CCKBR and $\mathrm{CgA}$ or HDC in almost all normal ECL- cells and ECL-derived tumor cells. There was also some degree of co-expression in adenocarcinoma of the diffuse and intestinal types, but to a much lesser extent than the NETs.

\section{Neuroendocrine Neoplasms}

Expression of CgA mRNA and CCKBR mRNA was noted in all eight (100\%) NENs examined. Only five cases were investigated with probe against HDC, all of these cases positive. For all probes, the highest number of dot-like structures was observed in NETs and the lowest number in NECs. The results of IHC and ISH are illustrated in Fig. 1. Interestingly, in case 7 (Fig. 2), all the stages from ECL cell hyperplasia, NET and NEC were observed, and further examination with IHC and ISH clearly demonstrated positivity for both $\mathrm{CgA}$ and 
Table 1 Staining results from 37 cases of stomach cancer. The amount of positive cells is given values ranging from 0 to 4 , where 0 indicates $<2 \%$ positive cells, 1 is $2-10 \%$ positive cells, 2 is 10 $40 \%$ positive cells, 3 is $40-70 \%$ positive cells, and 4 is $>70 \%$ positive cells

\begin{tabular}{|c|c|c|c|c|c|c|c|c|c|}
\hline \multirow[t]{2}{*}{ Case } & \multirow[t]{2}{*}{ Age } & \multirow[t]{2}{*}{ Gender } & \multirow[t]{2}{*}{ Tumor type } & \multirow{2}{*}{$\begin{array}{l}\text { Synaptophysin } \\
\text { IHC }\end{array}$} & \multicolumn{2}{|c|}{ Chromogranin A } & \multirow{2}{*}{$\begin{array}{l}\mathrm{HDC} \\
I S H\end{array}$} & \multicolumn{2}{|c|}{ CCKBR } \\
\hline & & & & & $I H C$ & $I S H$ & & $I H C$ & $I S H$ \\
\hline 1 & 69 & Female & NET & 4 & 2 & 4 & & 2 & 4 \\
\hline 2 & 66 & Male & NET & 4 & 4 & 4 & 2 & 4 & 4 \\
\hline 3 & 52 & Female & NET & 4 & 4 & 4 & 4 & 4 & 4 \\
\hline 4 & 49 & Female & NET & 4 & 4 & 4 & 4 & 4 & 4 \\
\hline 5 & 32 & Male & NET & 4 & 4 & 4 & & 1 & 4 \\
\hline 6 & 72 & Male & NET & 4 & 4 & 4 & & 4 & 4 \\
\hline 7 & 77 & Female & NEC & 3 & 2 & 1 & 1 & 3 & 2 \\
\hline 8 & 76 & Female & NEC & 4 & 3 & 4 & 2 & 0 & 4 \\
\hline 9 & 65 & Male & Intestinal & 0 & 0 & 1 & 0 & 2 & 1 \\
\hline 10 & 70 & Male & Intestinal & 2 & 0 & 1 & 1 & 2 & 1 \\
\hline 11 & 72 & Male & Intestinal & 0 & 0 & 1 & 0 & 2 & 1 \\
\hline 12 & 74 & Male & Intestinal & 0 & 0 & 1 & 0 & 3 & 3 \\
\hline 13 & 59 & Male & Intestinal & 0 & 0 & 0 & 1 & 2 & 0 \\
\hline 14 & 57 & Male & Intestinal & 0 & 0 & 1 & 0 & 0 & 1 \\
\hline 15 & 58 & Male & Intestinal & 2 & 0 & 0 & 0 & 2 & 0 \\
\hline 16 & 50 & Male & Intestinal & 0 & 0 & 0 & 0 & 1 & 0 \\
\hline 17 & 59 & Male & Intestinal & 0 & 0 & 0 & 0 & 2 & 0 \\
\hline 18 & 74 & Female & Intestinal & 1 & 1 & 1 & & 1 & 0 \\
\hline 19 & 67 & Female & Diffuse & 0 & 0 & 0 & 0 & 1 & 0 \\
\hline 20 & 69 & Female & Diffuse & 0 & 0 & 1 & 1 & 2 & 0 \\
\hline 21 & 77 & Male & Diffuse & 1 & 2 & 2 & & 3 & 2 \\
\hline 22 & 73 & Female & Diffuse & 2 & 2 & 2 & 1 & 2 & 1 \\
\hline 23 & 76 & Female & Diffuse & 0 & 0 & 1 & & 1 & 0 \\
\hline 24 & 79 & Male & Diffuse & 0 & 0 & 0 & & 1 & 0 \\
\hline 25 & 56 & Female & Diffuse & 0 & 0 & 1 & & 0 & 0 \\
\hline 26 & 72 & Female & Diffuse & 1 & 1 & 1 & & 1 & 3 \\
\hline 27 & 44 & Female & Diffuse & 1 & 1 & 1 & & 3 & 0 \\
\hline 28 & 67 & Male & Diffuse & 0 & 0 & 0 & 0 & 1 & 1 \\
\hline 29 & 56 & Male & Diffuse & 0 & 1 & 1 & & 1 & 0 \\
\hline 30 & 74 & Male & Diffuse & 0 & 0 & 0 & 0 & 2 & 0 \\
\hline 31 & 48 & Female & Diffuse & 0 & 0 & 1 & 0 & 1 & 0 \\
\hline 32 & 71 & Female & Diffuse & 0 & 0 & 1 & & 1 & 0 \\
\hline 33 & 49 & Female & Diffuse & 0 & 0 & 1 & & 2 & 1 \\
\hline 34 & 56 & Male & Mixed & 0 & 0 & 2 & 1 & 0 & 0 \\
\hline 35 & 52 & Male & Mixed & 0 & 0 & 0 & 1 & 1 & 0 \\
\hline 36 & 70 & Female & Mixed & 2 & 2 & 2 & & 1 & 1 \\
\hline 37 & 78 & Female & Mixed & 2 & 2 & 2 & 0 & 2 & 3 \\
\hline
\end{tabular}

NET neuroendocrine tumor, NEC neuroendocrine carcinoma, Intestinal adenocarcinoma of intestinal type according to Laurén, Diffuse adenocarcinoma of diffuse type according to Laurén, Mixed adenocarcinoma of mixed or indeterminate type, according to Laurén
CCKBR in all the various components of the tumor. The number of positive tumor cells in the less differentiated areas of the tumor was, however, low indicating dedifferentiation of the tumor tissue. Synaptophysin, on the other hand, was positive in most of the tumor cells. This tumor was originally diagnosed as indeterminate or diffuse type adenocarcinoma, partly due to IHC not being performed.

\section{Adenocarcinomas (Intestinal, Diffuse, and Mixed/Indeterminate Types)}

CgA mRNA was observed in 20 of $29(69 \%)$ adenocarcinomas, where six of ten $(60 \%)$ intestinal type, 11 of 15 (73\%) diffuse type, and three of four $(75 \%)$ mixed/ indeterminate type were positive. Of the 18 adenocarcinomas 
Fig. 1 Case 6, neuroendocrine tumor grade 1 in a patient with chronic atrophic gastritis illustrated by a Hematoxylin and eosin, $\times 20$, and by positive expression for $\mathbf{b}$ chromogranin $\mathrm{A}$, $\times 20$, c synaptophysin, $\times 20, \mathbf{d}$ cholecystokinin B receptor, $\times 20$, $\mathbf{e}$ in situ hybridization with two probes, illustrating co-expression of cholecystokinin B receptor (green/blue) and chromogranin A (red), $\times 40$, $\mathbf{f}$ in situ hybridization with dual expression of cholecystokinin $\mathrm{B}$ receptor and chromogranin A in neuroendocrine cells $($ blue $/$ green $=$ cholecys tokinin $\mathrm{B}$ receptor, red $=$ chromogranin $\mathrm{A}$, black $=$ dual expression), $\times 40$

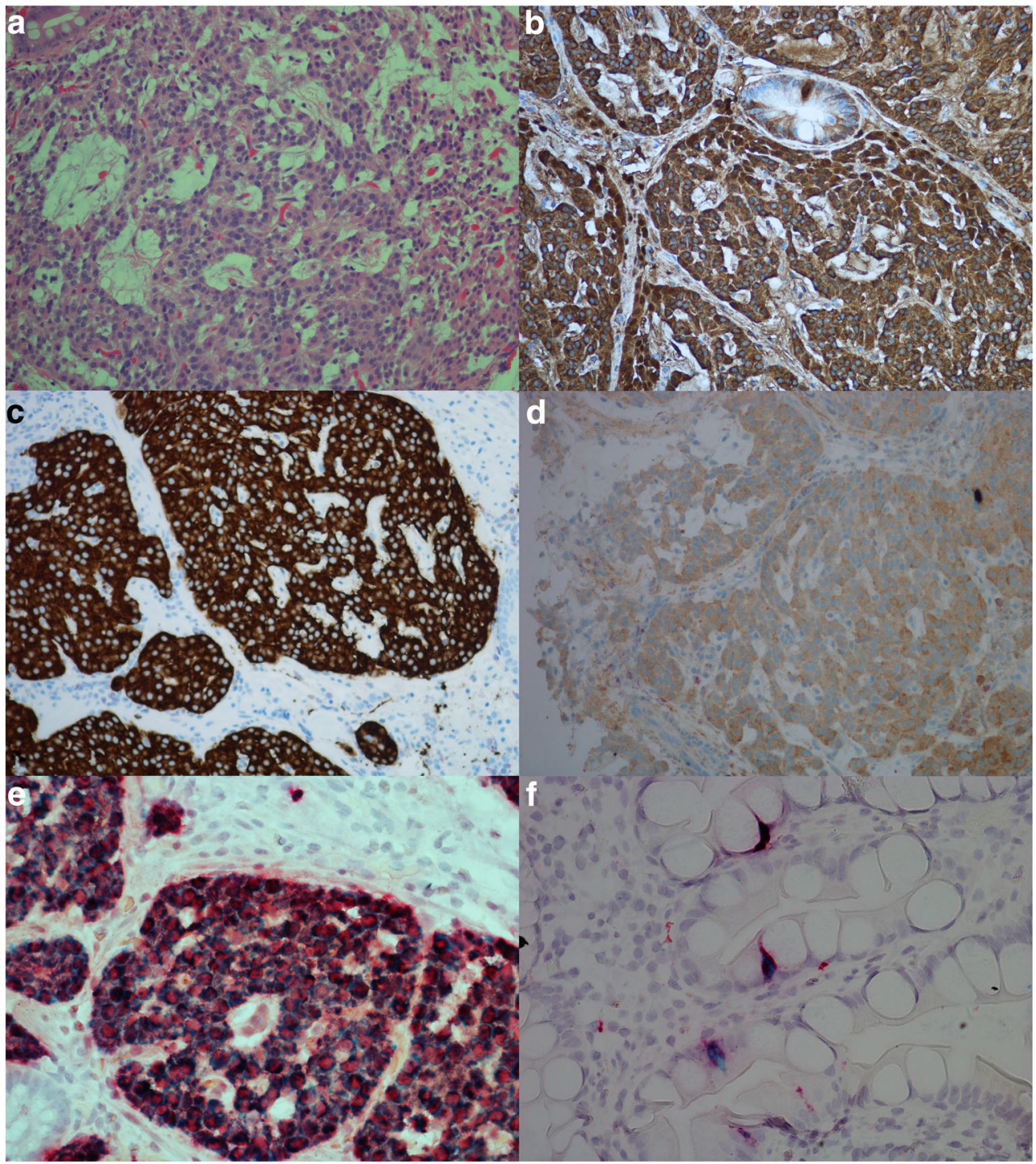

examined for HDC mRNA, two of nine (22\%) intestinal type, two of six (33\%) diffuse type, and two of three $(67 \%)$ mixed/ indeterminate type were positive. When examined for CCKBR mRNA 12 of $29(41 \%)$ adenocarcinomas expressed this marker, where five of ten (50\%) intestinal types, five of 15 (33\%) diffuse types and two of four (50\%) mixed/ indeterminate types expressed this marker. As an incidental finding, a GIST was observed in the stomach wall of case 26 (Fig. 3). This tumor was surrounded by mostly CCKBR negative carcinoma cells, but the GIST itself expressed copious amounts of CCKBR mRNA. A summary of staining results is found in Table 1, and illustration of results is found in Figs. 3 and 4 .

\section{Normal Gastric Mucosa}

When possible, gastric mucosa in close proximity to tumor was examined. In addition, separate biopsies from two patients, where one was from a patient with normal gastric mucosa and the other from a patient with Zollinger-Ellison syndrome, were also investigated. In the mucosa from the patient with Zollinger-Ellison, hyperplasia of ECL cells was observed. CCKBR mRNA was expressed in ECL cells and faintly in glandular cells below the isthmus area. The number of dot-like structures was higher in the ECL cell when compared to the other cell types. Further IHC investigations on normal gastric mucosa with antibodies against HKATPase and pepsinogen II showed parietal and chief cells to be among the weak CCKBR mRNA expressing cells (Fig. 5). This was not seen to the same extent in larger sections or in sections where the normal epithelium was replaced by intestinal metaplasia.

\section{Characteristics of Patients Expressing CCKBR mRNA}

Of the 29 adenocarcinomas examined, 12 tumors expressed CCKBR mRNA, and 11 of these tumors co-expressed $\mathrm{CgA}$ 


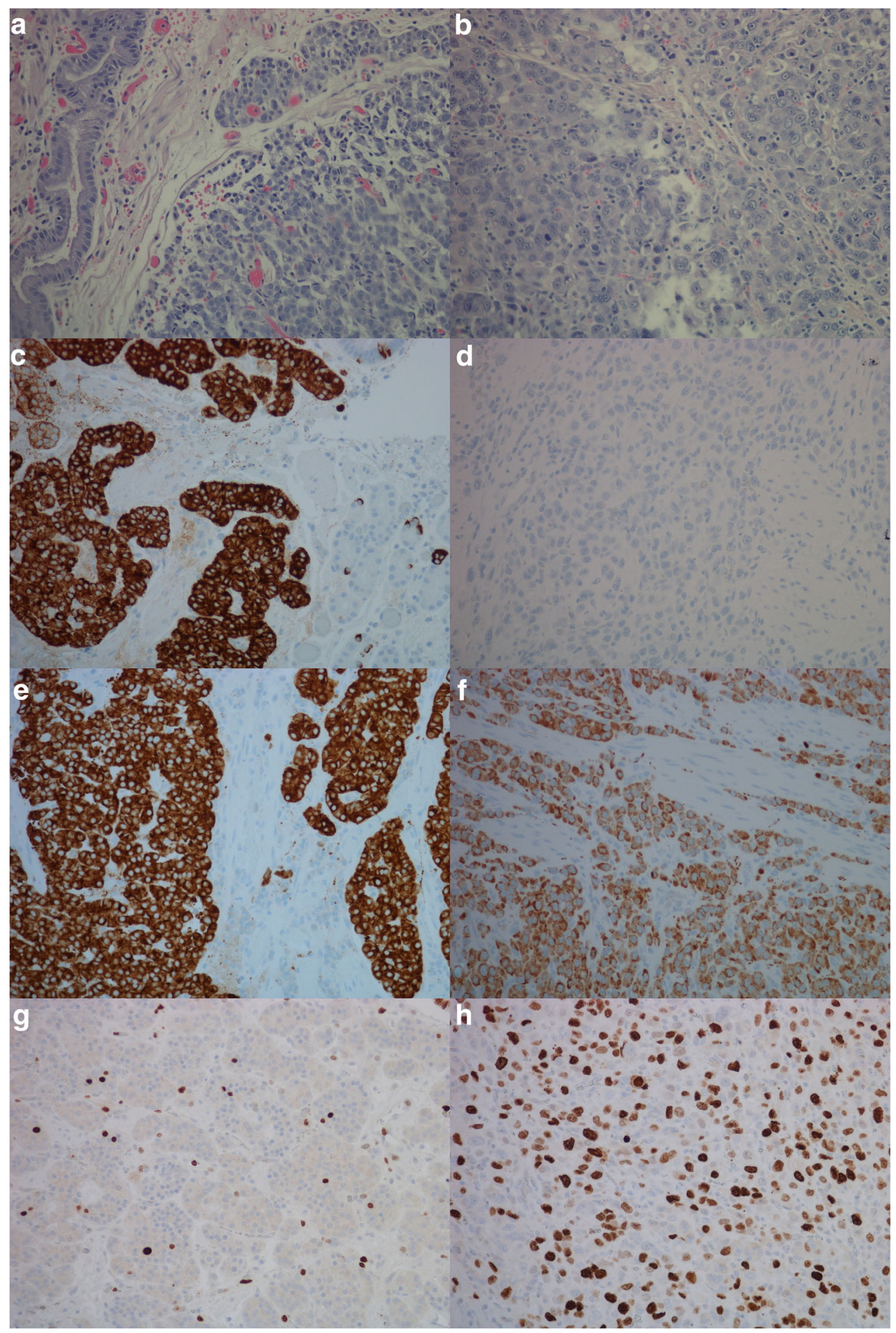

Fig. 2 Case 7, patient with enterochromaffin-like cell hyperplasia, neuroendocrine tumor and neuroendocrine carcinoma illustrated by, a hematoxylin and eosin, neuroendocrine tumor, $\times 20$, b hematoxylin and eosin, neuroendocrine carcinoma, $\times 20$, c chromogranin A positive neuroendocrine tumor, $\times 20$, d chromogranin A negative neuroendocrine carcinoma, $\times 20$, e synaptophysin positive neuroendocrine tumor, $\times 20, \mathbf{f}$ synaptophysin positive neuroendocrine carcinoma, $\times 20$, g Ki67

expression in $2-5 \%$ of tumor cells, neuroendocrine tumor, $\times 20$, h Ki67 expression in $>20 \%$ of tumor cells, neuroendocrine carcinoma, $\times 20$, i) cholecystokinin-B receptor protein expression, neuroendocrine tumor, $\times 20$, j) cholecystokinin-B receptor protein expression, neuroendocrine carcinoma $\times 20, \mathbf{k})$ in situ hybridization, cells with dual expression of cholecystokinin-B receptor and chromogranin A in neuroendocrine carcinoma (red/black/green), $\times 40$. Areas of co-localization appear black 

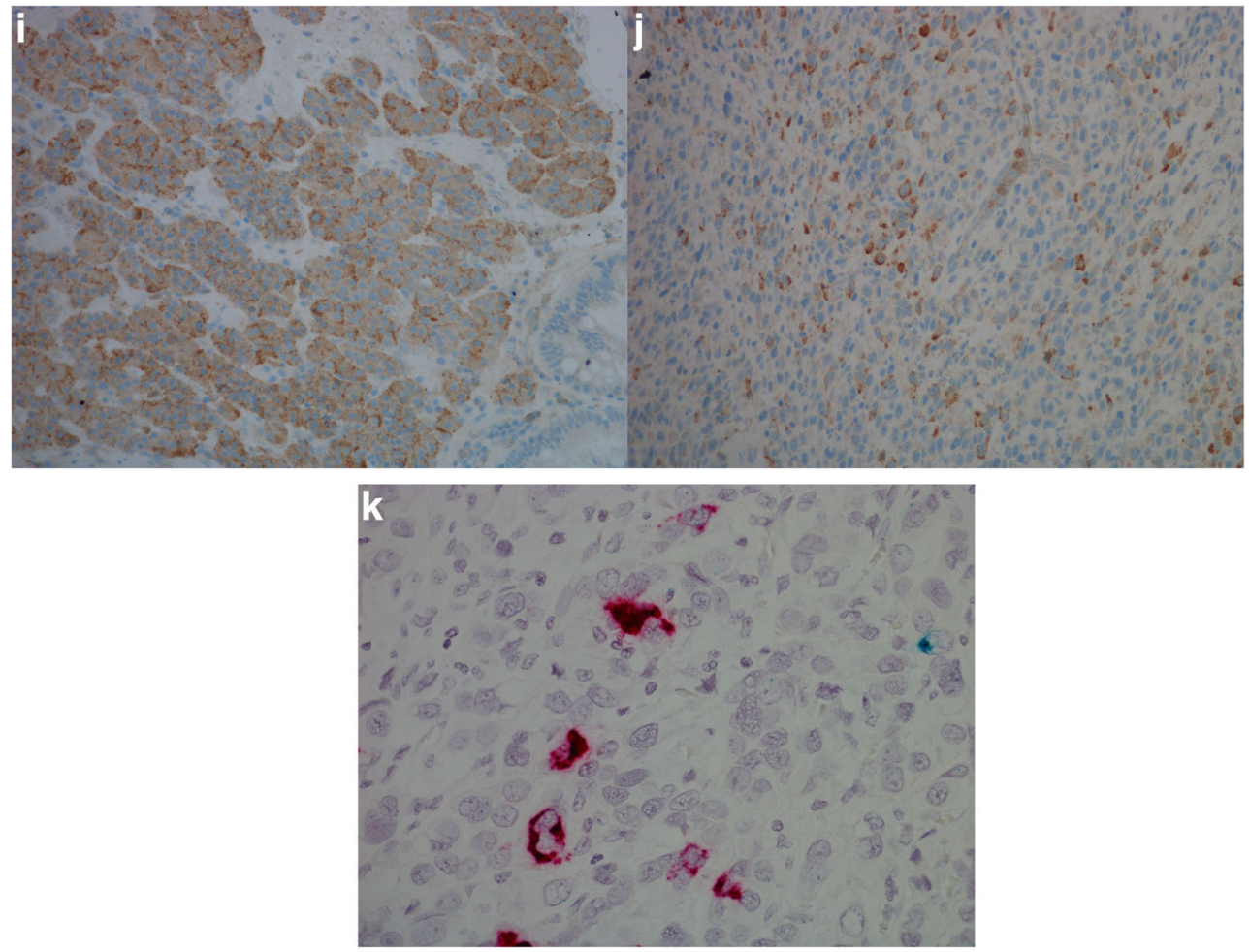

Fig. 2 (continued)

mRNA. Of the 12 CCKBR mRNA expressing tumors, five (42\%) were from women and seven $(58 \%)$ from men. Five (42\%) were adenocarcinoma of intestinal type, five (42\%) of diffuse type and two (17\%) of mixed/indeterminate type. Four tumors were located to the cardia/fundus region, five (42\%) to the corpus and three $(25 \%)$ to the antrum.

Fig. 3 Case 26. Gastrointestinal stromal tumor (GIST) with carcinoma cells of diffuse type in the periphery illustrated by $\mathbf{a}$ hematoxylin and eosin, $\times 20$, b positive expression for $\mathrm{CD} 117$ protein, $\times 20$, c pancytokeratin expression in carcinoma cells just next to GIST, $\times 20$, d in situ hybridization, expression of CCKBR mRNA (green/blue) in GIST, $\times 40$

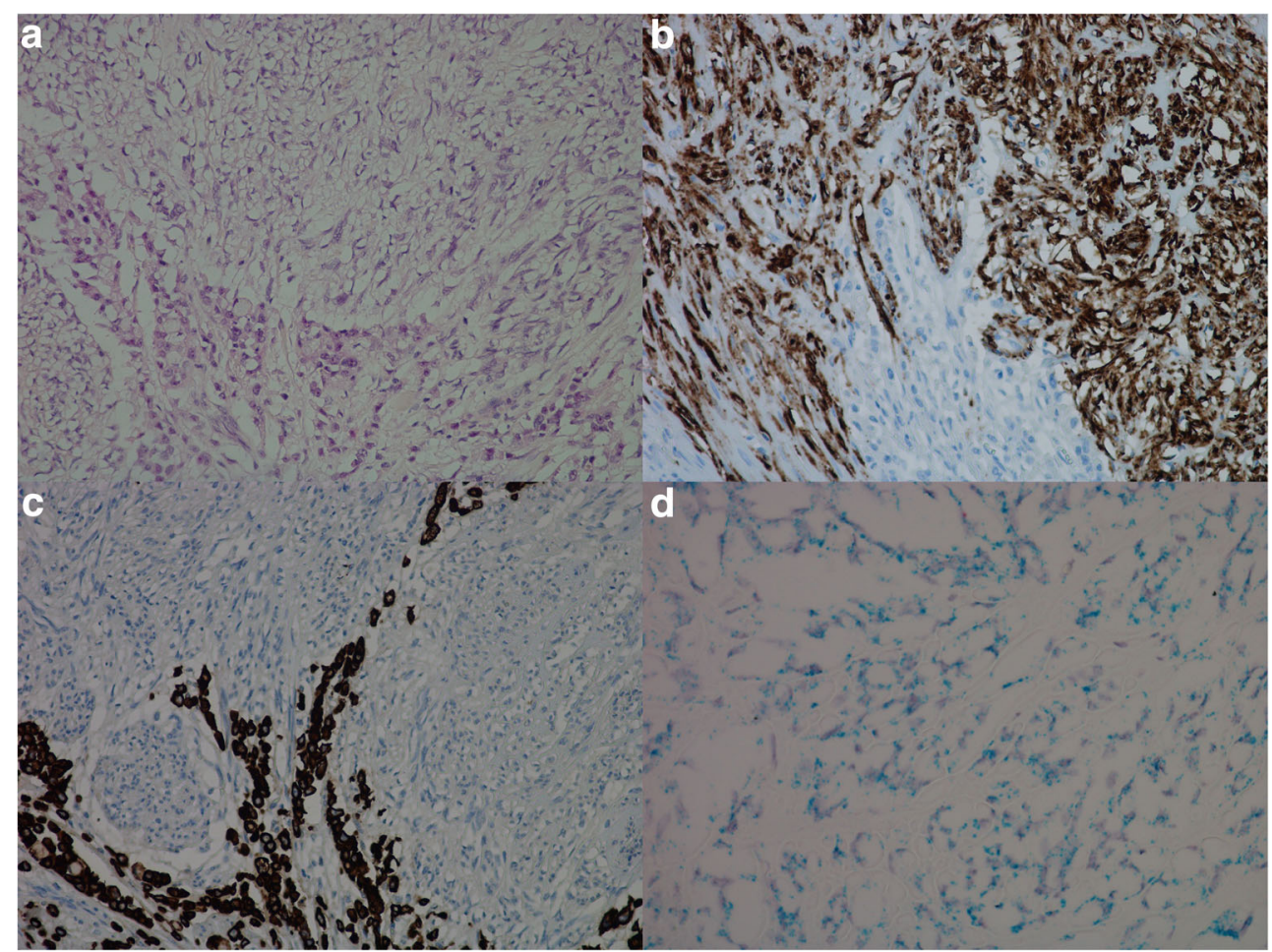


Fig. 4 Case 21. Adenocarcinoma of diffuse type illustrated by a hematoxylin and eosin, $\times 40$, b with chromogranin A (protein) positive cells, $\times 40$, c synaptophysin (protein) positive cells, $\times 40, \mathbf{d}$ cholecystokinin-B receptor (protein) positive cells, $\times 40$, and $\mathbf{e}$ in situ hybridization with dual expression of chromogranin A mRNA (red) and CCKBR mRNA (green/blue), $\times 40$ (areas of co-localization appear black)

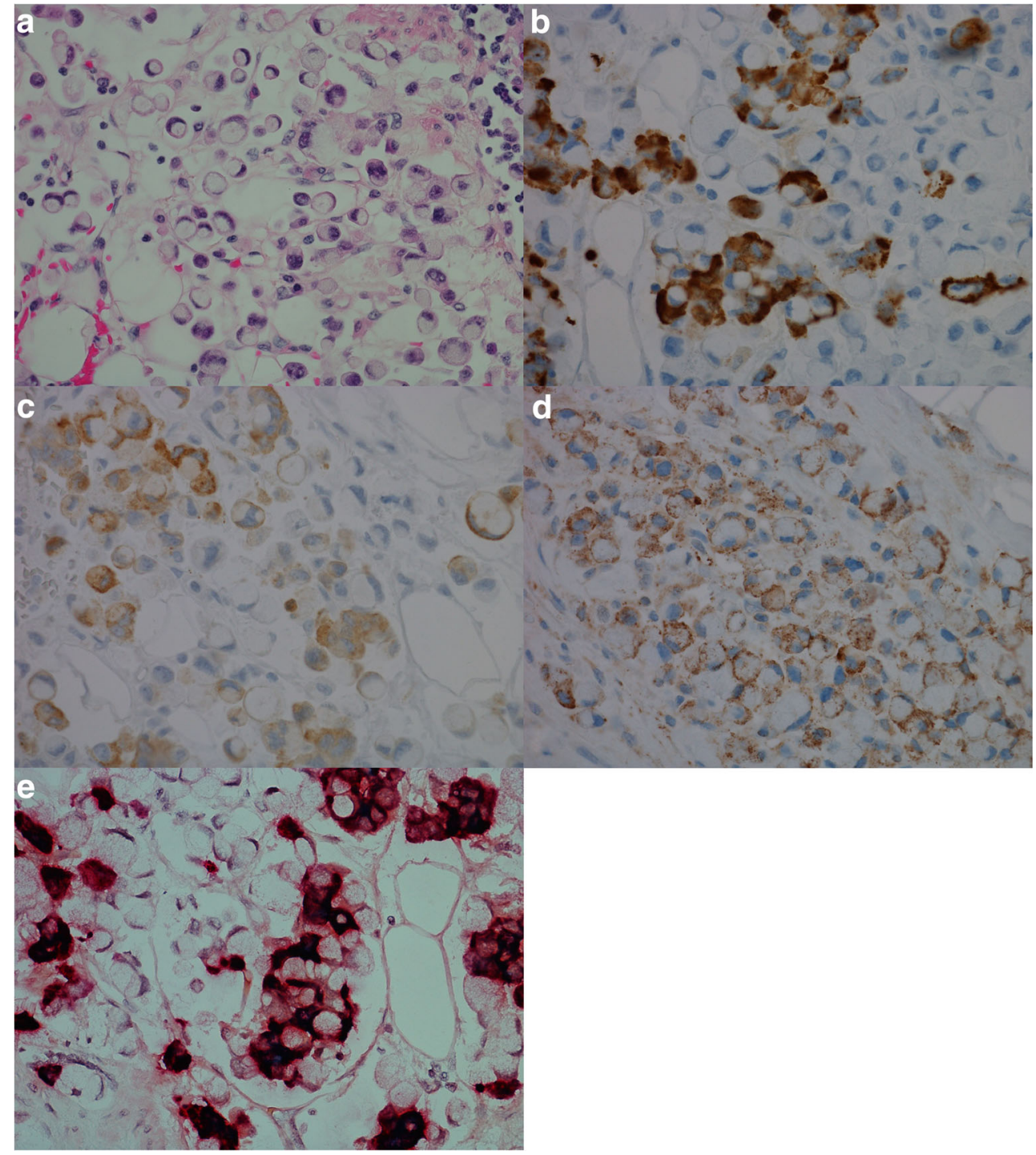

\section{Correlations}

When considering all 29 adenocarcinomas, there was a strong association between $\mathrm{CgA}$ protein and synaptophysin protein $(r=0.7, p<0.01)$, and $\mathrm{CgA}$ protein and $\mathrm{CgA}$ mRNA $(r=0.6$, $\mathrm{p}<0.01)$ ). There was a moderate, but significant association between CCKBR mRNA and CgA mRNA $(r=0.5, p<0.01)$. When considering the group consisting of CCKBR mRNA expressing tumors, a positive association between the expression of $\mathrm{CgA}$ protein and CgA mRNA was observed $(r=0.9, p<0.01)$. The association between CCKBR protein and CCKBR mRNA was weak and not statistically significant $(r=0.3, p=0.08)$.

\section{Discussion}

Our study, which we consider a qualitative study, demonstrates that CCKBR mRNA and CCKBR protein are expressed in normal ECL cells, ECL cell hyperplasia and NENs. Among the NENs, the expression of CCKBR was high in the NETs, and low in NECs. This can be explained by dedifferentiation of the tumor cells. Expression of CCKBR was also observed in a number of cases with adenocarcinoma of the diffuse and intestinal types, but in a lower number of tumor cells when compared with NENs. Co-expression of CCKBR mRNA and CgA mRNA and CCKBR mRNA and HDC mRNA was frequently observed, which makes sense as the NENs and even some cases of adenocarcinomas of the diffuse type are thought to originate from ECL cells [7]. There was no significant association between the expression of CCKBR protein and CCKBR mRNA, and quite a number of cases expressing CCKBR protein did not express CCKBR mRNA, which partially could be due to poor mRNA quality of the larger sections, variable fixation time and variable age and condition of the tissue blocks. The choice of antibody may be of relevance, as the antibody used in this study was a 
Fig. 5 Normal gastric mucosa from a patient with ZollingerEllison syndrome illustrated by a hematoxylin and eosin, $\times 10$, b chromogranin A (protein) positive neuroendocrine cells, $\times 10$, c cholecystokinin-B receptor (protein) expression in normal gastric mucosa, $\times 10$, and d in situ hybridization (duplex) illustrating dual expression of cholecystokinin-B receptor mRNA (green/blue) and chromogranin A mRNA (red) in neuroendocrine cell (dual expression appearing black), and cholecystokinin-B receptor positive cells in other epithelial cells below the isthmus of the gastric gland

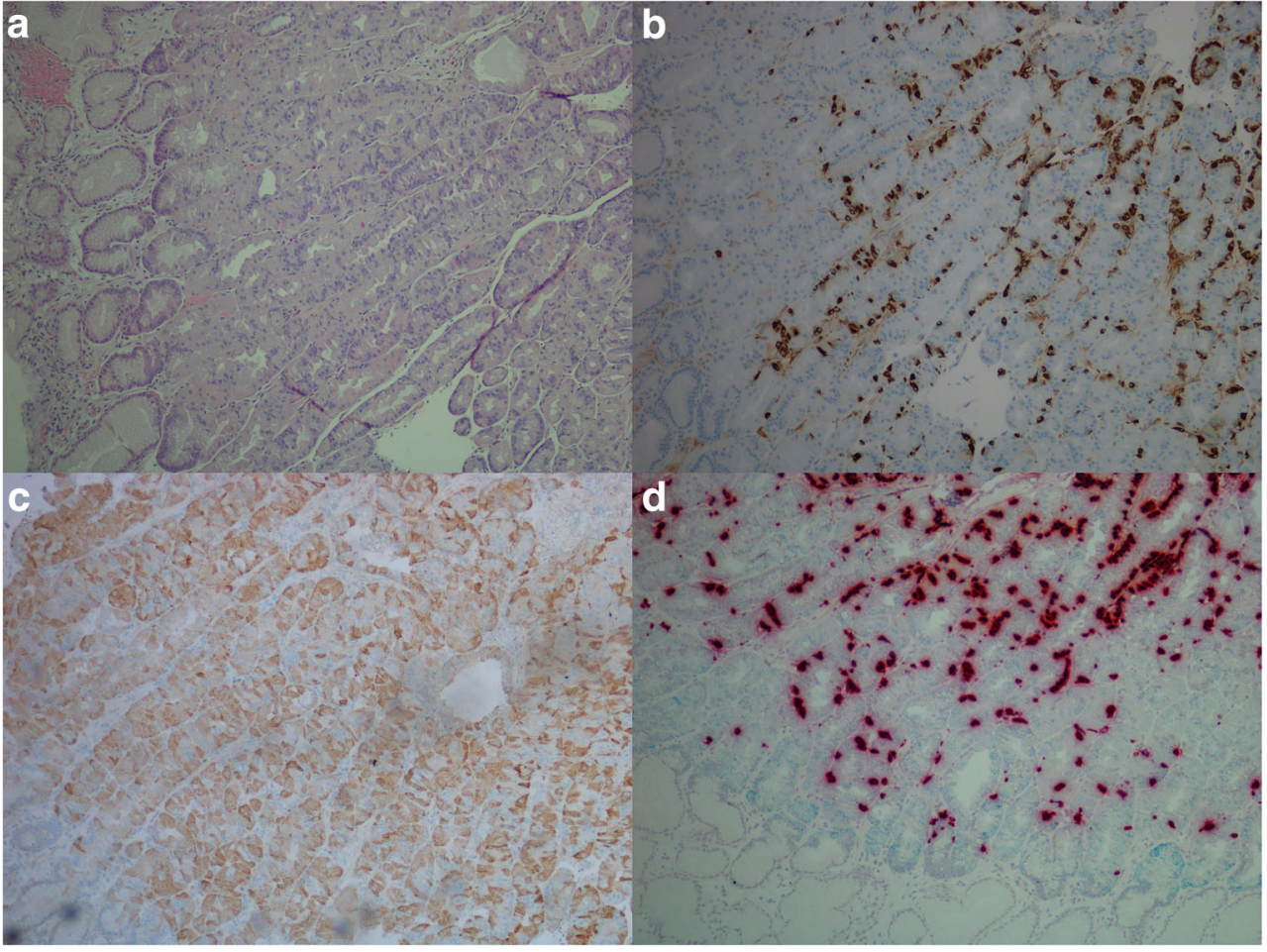

polyclonal rabbit antibody. Polyclonal antibodies are known to give more background staining compared to monoclonal antibodies, which are considered more specific. Moreover, polyclonal antibodies are not specific enough to ensure that the antibody binds exclusively to the CCKBR. Even a sequence in a monoclonal antibody directed towards the CCKBR may not be specific enough to guarantee this, as the specific sequence in question may react with other receptors with the very same epitope. The strongest CCKBR protein expression was observed in the NENs. Surprisingly though, one of the NECs (case 8) with high CCKBR mRNA expression did not express any CCKBR protein in the tumor. A GIST, which was incidentally found in the stomach wall of case 26, expressed ample amounts of CCKBR mRNA. This was not seen to the same degree in the surrounding carcinoma cells. Finding of CCKBR in GISTs, which are thought to originate from interstitial cells of Cajal, has also been described in previous study [27].

Of the adenocarcinomas located to the antrum, three were intestinal type and four of diffuse type. Further investigations revealed that six of them expressed $\mathrm{CgA}$ mRNA, three (two intestinal and one diffuse) expressed CCKBR mRNA, whereas none expressed HDC mRNA. A study by Choi et al. demonstrated that the antral mucosa contains a mixture of oxyntic glands and antral glands containing gastrin-producing cells [28]; thus, this may partly explain the presence of CCKBR mRNA expression in tumors originating from the antrum.

Gastrin exerts its effects by binding to CCKBR in the stomach and is involved in secretion of acid and cellular proliferation. Whether gastrin has a dominating role in the development of gastric carcinoma has been under debate. Studies on rats have revealed that hypergastrinemia results in the development of ECL-derived NETs [29, 30]. On the other hand, hypergastrinemia in insulin-gastrin (InsGas) transgenic mice causes gastric adenocarcinoma which is not accompanied by hyperplasia of ECL cells [31]. Gastrin stimulates function (histamine release) and ECL cell proliferation in a parallel way. The intracellular down-stream mechanisms for the interaction of gastrin with its receptor have been examined mainly around year 2000 by transfection of the receptor to cell lines $[32,33]$ and in the cell with CCKBR, the ECL cell [34]. These studies showed that gastrin to CCKBR interaction results in phosphoinositol breakdown leading to a rapid $\mathrm{Ca}^{2+}$ release activating protein kinase $\mathrm{D}$ and MEK-dependent ERK activation as well as increased cyclins: all involved in the regulation of proliferation. In order to further explore the effects of gastrin on gastric cancer cells, further studies are needed. Detection of intracellular signal substances will not necessarily prove that gastrin has a positive trophic effect on gastric cancer cells; thus, biological effects of gastrin are better demonstrated by confirming an inhibitory effect of a CCKBR antagonist on such tumors in vivo. As a hormone has direct effects only on cells having the receptor, patients selected for such a trial would need to express CCKBR on their tumor cells.

A close relationship between gastric NENs and adenocarcinomas of the stomach has been described [35], and the preservation of the CCKBR on gastric cancer cells may similarly 
to gastric NETs make them susceptible for treatment with a CCKBR antagonist (netazepide). Hypergastrinemia is a known cause of NENs in humans. Various studies done on mastomys [36] and other rodents [29, 37] discovered the development of adenocarcinomas in the stomach after prolonged acid suppression. Mastomys are genetically predisposed to developing NETs in the stomach, which is thought to be due to an abnormality in the CCKBR itself [38, 39]. Acid suppression in this rodent further amplifies the development of NETs. The study by Soga et al. led to a reclassification of adenocarcinomas to neuroendocrine carcinomas in the mastomys. A few studies in man led to similar findings [40]. Studies done by our group have demonstrated that a proportion of human gastric adenocarcinomas express NE markers, suggesting that some of these tumors may originate from enterochromaffin like (ECL) cells [4]. By using more sensitive methods, we were able to demonstrate that a substantial number of adenocarcinomas of the diffuse type express NE markers, supporting this view $[5,41]$. Interestingly, most tumors removed from patients with hypergastrinemia due to pernicious anemia expressed NE markers suggestive of ECL cell origin [42]. This finding is especially convincing among adenocarcinomas of the diffuse type [7]. The ECL cell may develop into malignant tumors by steps of ECL cell hyperplasia, neuroendocrine tumor (NET), and, finally, carcinoma [6]. Case 7 (Fig. 2) demonstrates this. From this, it is quite clear that the location of CCKBR is important for the carcinogenic process in hypergastrinemia.

The finding of NE markers in NETs and NECs is not surprising as the classification of these tumors is based on a specific morphology and/or the expression of NE markers in these tumors. As NENs in the stomach are thought to derive from ECL cells, which in turn are influenced by gastrin levels, the finding of CCKBR mRNA in these tumors is also expected. Patients with known NETs in the stomach treated with the CCKBR antagonists (netazepide) have experienced partial and even complete remission, supporting the notion that CCKBR is expressed in these tumors [14]. Furthermore, both NETs and carcinomas are associated with autoimmune gastritis and Helicobacter pylori (Hp) gastritis [8, 20]. Hypergastrinemia in patients with gastric carcinoma has also been reported [9, 10, 43]. Some of these tumors, especially adenocarcinomas of the diffuse type, express NE markers indicating ECL cell origin [5, 6, 42]. Therefore, the expression of CCKBR (in $90 \%$ of adenocarcinomas by IHC, and $41 \%$ by ISH) was not unexpected.

Helicobacter pylori infection is considered to be the main factor in gastric carcinogenesis. The role of gastrin in gastric cancer cannot, however, be overlooked as some studies have demonstrated hypergastrinemia in patients with these cancers [9, 10, 43]. Examination of CCKBR may help to tailor treatment, and if a tumor expresses CCKBR, a CCKBR antagonist may be applied. The CCKBR antagonist, netazepide, aids in preventing the formation of gastric NETs in mastomys [44]. Similar findings are observed in humans, and a reduction in both size and number of gastric NETs are observed in patients given this drug $[45,46]$. The CCKBR antagonist netazepide also reduces the density of ECL cells in flat gastric mucosa in those patients with NETs due to atrophic gastritis [15].

In most of the tissue samples we examined, the normal gastric mucosa was replaced by tumor tissue or CAG. The gastric mucosa in CAG showed CCKBR mRNA in only ECL cells. In a few smaller biopsies from normal gastric mucosa and gastric mucosa from a patient with Zollinger-Ellison syndrome, weak expression of CCKBR mRNA was in addition to ECL cells noted in gastric epithelial cells below the isthmus of the glands. The amount of CCKBR mRNA was clearly higher in the ECL cells compared with other cells in the gastric mucosa. The same was observed at protein level. These findings were mainly observed in smaller and more recent biopsies, not in larger and older samples. Overfixation and long-time storage of samples may destroy the mRNA in the tissue [47]. Various physiological studies have found the CCKBR receptor to be localized on ECL cells in the gastric corpus and fundus [48-50]. Kopin et al. were able to clone CCKBR from enriched canine parietal cells. This preparation was, however, only $95 \%$ pure still making it possible that the receptor was cloned from non-parietal cells [16]. The presence of CCKBR on the ECL cell has been undisputed since the CCKBR receptor was cloned from ECL derived NETs [51]. The cellular localization of CCKBR, on the other hand, has been disputed from the time the three major secretagogues of gastric acid secretion, acetylcholine, gastrin and histamine were discovered, and particularly the relationship between gastrin and histamine in this stimulation. Various studies established that gastrin was central in the physiological regulation of gastric acid secretion [52-56]. However, the interaction between gastrin and histamine was not settled. Black and co-workers showed that also histamine was a physiological regulator of acid secretion [53]. Berglindh and Öbrink demonstrated that a cholinergic compound as well as histamine stimulated aminopyrine uptake in glands/cells from rabbit, whereas gastrin was without any effect strongly indicating that there was no CCKBR on the parietal cell [54]. Soll, on the other hand, studied isolated canine cells from the oxyntic mucosa and reported a very faint effect by gastrin compared with a cholinergic agent and histamine [55]. Histamine is, however, much more potent in canine parietal cells compared with other species so the faint and inconsistent effect by gastrin could have been due to stimulation by histamine released from neighboring ECL cells. In fact, some years later, we found that gastrin only stimulated aminopyrine uptake in those preparations where gastrin also increased histamine concentration [56]. Shortly afterwards Prinz and co-workers described the regulation of the histamine release from isolated ECL cells [57]. The totally isolated vascularized perfused rat stomach 
allowed us to determine acid secretion and histamine concomitantly [48], and we could show that the histamine release was sufficient to explain the acid stimulation by gastrin [58]. Finally, Athman and co. workers studied rabbit isolated oxyntic glands using confocal microscopy to assess intracellular $\mathrm{Ca}^{2+}$ concentration [59]. They found that gastrinstimulated increase in intracellular $\mathrm{Ca}^{2+}$ in parietal cells could be blocked by a histamine-2 blocker up to a gastrin concentration of $1000 \mathrm{pM}$, but when increasing the gastrin concentration further ten times, the histamine-2 blocker could no longer block the effect [59]. As we see it, this does not indicate a separate CCKBR on the parietal cell, but more likely interference with a structurally related receptor on the parietal cell. Rangachari and McWade studied canine isolated oxyntic mucosa in Ussing chambers and found that pentagastrin in contrast to histamine stimulated acid secretion inconsistently, and more importantly very short-lived which could be due exhaustion of stored histamine [60]. The trophic effects of gastrin are also a part of the functional effects of gastrin. Gastrin has a selective trophic effect on the ECL cell and a general effect on the other oxyntic mucosal cells [61]. The general effect can be explained by stimulation of the stem cell either by a CCKBR there or indirectly by a mediator released from the ECL cell for instance Reg protein [62]. For inducing an effect, gastrin has to bind to its receptor. Binding studies will therefore reflect possible biological effects [63]. During the last decades, there have been many attempts to localize the CCKBR by immunohistochemistry [64-66], but there have been problems due to lack of specificity of the antibodies, presumably due to binding to structurally related receptors. In the present study, we have tried to improve the specificity by doing in situ hybridization as well, but even constructed probes may not be completely specific. A Danish study assessed CCKBR mRNA by real time PCR and receptor protein by western blotting in 20 gastric adenocarcinomas and found both in all tumors [67]. To conclude the question of the localization of CCKBR in normal stomach, the results have been divergent, but we will underline that functional results probably are the most reliable ones. Therefore, the receptor is localized to the ECL cell without doubt, whereas other locations are uncertain.

\section{Conclusion}

In summary, we found that all NENs expressed NE markers and CCKBR. The expression of these markers were, however, lower in NECs compared with the NETs probably due to dedifferentiation of the tumor. The same markers were also expressed in a proportion of adenocarcinomas of the diffuse and intestinal type, incriminating gastrin in the development of gastric cancer. Thus, targeting the CCKBR may be an option when treating carcinomas of the stomach, and perhaps this may improve the now dismal prognosis of this disease.
Therefore, the determination of CCKBR (gastrin receptor) in gastric carcinoma cells will help to select patients for treatment trials with netazepide and is also important for the understanding of gastric carcinogenesis.

Acknowledgements We thank the Department of Pathology at St. Olav's Hospital - Trondheim University Hospital, Norway, for making the archives available for the study, and Bjørn Munkvold for technical assistance. Information about patient deaths was given to us by the National Registry. The project was funded by The Liaison Committee between the Central Norway Regional Health Authority (RHA) and the Norwegian University of Science and Technology (NTNU) ("Samarbeids organet").

Authors' Contributions PM evaluated the hematoxylin and eosinstained sections, as well as performing and evaluating the immunohistochemical staining and in situ hybridization. Statistical analysis was done by PM and LS. HW designed the study. IN, RF, LS, and AKS were involved in patient collection for the study, and ØS, HW, and IN were involved in evaluating the quality of the immunohistochemical and in situ hybridization techniques. All authors revised and approved the final manuscript.

\section{Compliance with Ethical Standards}

Conflict of Interest The authors declare that they have no conflict of interest.

Open Access This article is distributed under the terms of the Creative Commons Attribution 4.0 International License (http:// creativecommons.org/licenses/by/4.0/), which permits unrestricted use, distribution, and reproduction in any medium, provided you give appropriate credit to the original author(s) and the source, provide a link to the Creative Commons license, and indicate if changes were made.

\section{References}

1. Ferlay J, Soerjomataram I, Dikshit R, Eser S, Mathers C, Rebelo M, Parkin DM, Forman D, Bray F (2015) Cancer incidence and mortality worldwide: sources, methods and major patterns in GLOBOCAN 2012. Int J Cancer 136(5):E359-E386. https://doi. org/10.1002/ijc. 29210

2. Lauren P (1965) The two histological main types of gastric carcinoma, an attempt at a histoclinical classification. Acta Pathol Microbiol Scand 64:31-49

3. Fuchs CS, Mayer RJ (1995) Gastric carcinoma. N Engl J Med 333(1):32-41. https://doi.org/10.1056/nejm199507063330107

4. Waldum H, Haugen O, Isaksen C, Mecsei R, Sandvik A (1991) Are diffuse gastric carcinomas neuroendocrine tumours (ECL-omas)? Eur J Gastroenterol Hepatol 3:249-249

5. Waldum HL, Aase S, Kvetnoi I, Brenna E, Sandvik AK, Syversen U, Johnsen G, Vatten L, Polak JM (1998) Neuroendocrine differentiation in human gastric carcinoma. Cancer 83(3):435-444

6. Fossmark R, Zhao CM, Martinsen TC, Kawase S, Chen D, Waldum HL (2005) Dedifferentiation of enterochromaffin-like cells in gastric cancer of hypergastrinemic cotton rats. Acta Pathol Microbiol Immunol Scand 113(6):436-449. https://doi.org/10.1111/j.16000463.2005.apm_134.x

7. Bakkelund K, Fossmark R, Nordrum I, Waldum H (2006) Signet ring cells in gastric carcinomas are derived from neuroendocrine 
cells. J Histochem Cytochem Off J Histochem Soc 54(6):615-621. https://doi.org/10.1369/jhc.5A6806.2005

8. Kokkola A, Sjoblom SM, Haapiainen R, Sipponen P, Puolakkainen P, Jarvinen H (1998) The risk of gastric carcinoma and carcinoid tumours in patients with pernicious anaemia. A prospective followup study. Scand J Gastroenterol 33(1):88-92

9. Rakic S, Milicevic MN (1991) Serum gastrin levels in patients with intestinal and diffuse type of gastric cancer. Br J Cancer 64(6):1189

10. McGuigan JE, Trudeau WL (1973) Serum and tissue gastrin concentrations in patients with carcinoma of the stomach. Gastroenterology 64(1):22-25

11. Rindi G, Luinetti O, Cornaggia M, Capella C, Solcia E (1993) Three subtypes of gastric argyrophil carcinoid and the gastric neuroendocrine carcinoma: a clinicopathologic study. Gastroenterology 104(4):994-1006

12. Kloppel G, Perren A, Heitz PU (2004) The gastroenteropancreatic neuroendocrine cell system and its tumors: the WHO classification. Ann N Y Acad Sci 1014:13-27

13. Asahara M, Kinoshita Y, Nakata H, Matsushima Y, Naribayashi Y, Nakamura A, Matsui T, Chihara K, Yamamoto J, Ichikawa A et al (1994) Gastrin receptor genes are expressed in gastric parietal and enterochromaffin-like cells of Mastomys natalensis. Dig Dis Sci 39(10):2149-2156

14. Boyce M, Moore AR, Sagatun L, Parsons BN, Varro A, Campbell F, Fossmark R, Waldum HL, Pritchard DM (2016) Netazepide, a gastrin/cholecystokinin-2 receptor antagonist, can eradicate gastric neuroendocrine tumours in patients with autoimmune chronic atrophic gastritis. Br J Clin Pharmacol. https://doi.org/10.1111/bcp. 13146

15. Sagatun L, Mjones P, Jianu CS, Boyce M, Waldum HL, Fossmark $\mathrm{R}$ (2016) The gastrin receptor antagonist netazepide (YF476) in patients with type 1 gastric enterochromaffin-like cell neuroendocrine tumours: review of long-term treatment. Eur J Gastroenterol Hepatol 28(11):1345-1352. https://doi.org/10.1097/meg. 0000000000000713

16. Kopin AS, Lee YM, McBride EW, Miller LJ, Lu M, Lin HY, Kolakowski LF Jr, Beinborn M (1992) Expression cloning and characterization of the canine parietal cell gastrin receptor. Proc Natl Acad Sci U S A 89(8):3605-3609

17. Stone TW (1993) Acetylcholine, sigma receptors, cck and eicosanoids, neurotoxins, vol 2. Taylor \& Francis, Routledge

18. Munoz N, Asvall J (1971) Time trends of intestinal and diffuse types of gastric cancer in Norway. Int J Cancer 8(1):144-157

19. Kaneko S, Yoshimura T (2001) Time trend analysis of gastric cancer incidence in Japan by histological types, 1975-1989. Br J Cancer 84(3):400-405. https://doi.org/10.1054/bjoc.2000.1602

20. Parsonnet J, Friedman GD, Vandersteen DP, Chang Y, Vogelman JH, Orentreich N, Sibley RK (1991) Helicobacter pylori infection and the risk of gastric carcinoma. N Engl J Med 325(16):11271131. https://doi.org/10.1056/nejm199110173251603

21. Solcia E, Capella C, Fiocca R, Rindi G, Rosai J (1990) Gastric argyrophil carcinoidosis in patients with Zollinger-Ellison syndrome due to type 1 multiple endocrine neoplasia. A newly recognized association. Am J Surg Pathol 14(6):503-513

22. Borch K, Renvall H, Liedberg G (1985) Gastric endocrine cell hyperplasia and carcinoid tumors in pernicious anemia. Gastroenterology 88(3):638-648

23. Bosman FT, Carneiro F, Hruban RH, Theise ND (2010) WHO classification of tumours of the digestive system, 4th edn. World Health Organization classification of tumours, Lyon

24. Cancer Staging Manual AJCC (2017) vol 1, 8th edn Springer Nature

25. Mjones PG, Nordrum IS, Qvigstad G, Sordal O, Rian LL, Waldum HL (2017) Expression of erythropoietin and neuroendocrine markers in clear cell renal cell carcinoma. Acta Pathol Microbiol
Immunol Scand 125(3):213-222. https://doi.org/10.1111/apm. 12654

26. McShane LM, Altman DG, Sauerbrei W, Taube SE, Gion M, Clark GM (2005) REporting recommendations for tumor MARKer prognostic studies (REMARK). Nat Clin Pract Urol 2(8):416-422

27. Quattrone A, Dewaele B, Wozniak A, Bauters M, Vanspauwen V, Floris G, Schoffski P, Chibon F, Coindre JM, Sciot R, DebiecRychter M (2012) Promoting role of cholecystokinin 2 receptor (CCK2R) in gastrointestinal stromal tumour pathogenesis. J Pathol 228(4):565-574. https://doi.org/10.1002/path.4071

28. Choi E, Roland JT, Barlow BJ, O'Neal R, Rich AE, Nam KT, Shi C, Goldenring JR (2014) Cell lineage distribution atlas of the human stomach reveals heterogeneous gland populations in the gastric antrum. Gut 63(11):1711-1720. https://doi.org/10.1136/gutjnl-2013305964

29. Havu N (1986) Enterochromaffin-like cell carcinoids of gastric mucosa in rats after life-long inhibition of gastric secretion. Digestion 35(Suppl 1):42-55

30. Havu N, Mattsson H, Ekman L, Carlsson E (1990) Enterochromaffin-like cell carcinoids in the rat gastric mucosa following long-term administration of ranitidine. Digestion 45(4): 189-195

31. Wang TC, Dangler CA, Chen D, Goldenring JR, Koh T, Raychowdhury R, Coffey RJ, Ito S, Varro A, Dockray GJ, Fox JG (2000) Synergistic interaction between hypergastrinemia and Helicobacter infection in a mouse model of gastric cancer. Gastroenterology 118(1):36-47

32. Seufferlein T, Withers DJ, Broad S, Herget T, Walsh JH, Rozengurt $\mathrm{E}$ (1995) The human CCKB/gastrin receptor transfected into rat1 fibroblasts mediates activation of MAP kinase, p74raf-1 kinase, and mitogenesis. Cell Growth Diff Mol Biol J Am Assoc Cancer Res 6(4):383-393

33. Zhukova E, Sinnett-Smith J, Wong H, Chiu T, Rozengurt E (2001) $\mathrm{CCK}(\mathrm{B}) /$ gastrin receptor mediates synergistic stimulation of DNA synthesis and cyclin D1, D3, and E expression in Swiss 3 T3 cells. J Cell Physiol 189(3):291-305. https://doi.org/10.1002/jcp.10018

34. Zanner R, Hapfelmeier G, Gratzl M, Prinz C (2002) Intracellular signal transduction during gastrin-induced histamine secretion in rat gastric ECL cells. Am J Physiol Cell Physiol 282(2):C374-C382. https://doi.org/10.1152/ajpcell.00366.2001

35. Wilander E, El-Salhy M, Pitkanen P (1984) Histopathology of gastric carcinoids: a survey of 42 cases. Histopathology 8(2):183-193

36. Soga J, Tazawa K, Kanahara H, Hiraide K (1969) Some characteristic features of spontaneous argyrophil cell carcinoids in glandular stomach of Praomys (Mastomys) natalensis. GANN Monogr 8:15-26

37. Poynter D (1985) Long-term effects of reduced gastric acidity in laboratory animals. Digestion 26(31):174

38. Willard MD, Lajiness ME, Wulur IH, Feng B, Swearingen ML, Uhlik MT, Kinzler KW, Velculescu VE, Sjoblom T, Markowitz SD, Powell SM, Vogelstein B, Barber TD (2012) Somatic mutations in CCK2R alter receptor activity that promote oncogenic phenotypes. Mol Cancer Res 10(6):739-749. https://doi.org/10.1158/ 1541-7786.mcr-11-0483

39. Tang LH, Luque EA, Efstathiou JA, Bortecen KH, Kidd M, Tarasova NI, Modlin IM (1997) Gastrin receptor expression and function during rapid transformation of the enterochromaffin-like cells in an African rodent. Regul Pept 72(1):9-18

40. Azzopardi JG, Pollock DJ (1963) Argentaffin and argyrophil cells in gastric carcinoma. J Pathol Bacteriol 86:443-451

41. Qvigstad G, Sandvik AK, Brenna E, Aase S, Waldum HL (2000) Detection of chromogranin A in human gastric adenocarcinomas using a sensitive immunohistochemical technique. Histochem J 32(9):551-556

42. Qvigstad G, Qvigstad T, Westre B, Sandvik AK, Brenna E, Waldum HL (2002) Neuroendocrine differentiation in gastric 
adenocarcinomas associated with severe hypergastrinemia and/or pernicious anemia. Acta Pathol Microbiol Immunol Scand 110(2): $132-139$

43. Fossmark R, Sagatun L, Nordrum IS, Sandvik AK, Waldum HL (2015) Hypergastrinemia is associated with adenocarcinomas in the gastric corpus and shorter patient survival. Acta Pathol Microbiol Immunol Scand 123(6):509-514. https://doi.org/10.1111/apm. 12380

44. Kidd M, Siddique ZL, Drozdov I, Gustafsson BI, Camp RL, Black JW, Boyce M, Modlin IM (2010) The CCK(2) receptor antagonist, YF476, inhibits Mastomys ECL cell hyperplasia and gastric carcinoid tumor development. Regul Pept 162(1-3):52-60. https://doi. org/10.1016/j.regpep.2010.01.009

45. Fossmark R, Sordal O, Jianu CS, Qvigstad G, Nordrum IS, Boyce M, Waldum HL (2012) Treatment of gastric carcinoids type 1 with the gastrin receptor antagonist netazepide (YF476) results in regression of tumours and normalisation of serum chromogranin A. Aliment Pharmacol Ther 36(11-12):1067-1075. https://doi.org/ 10.1111/apt.12090

46. Moore AR, Boyce M, Steele IA, Campbell F, Varro A, Pritchard DM (2013) Netazepide, a gastrin receptor antagonist, normalises tumour biomarkers and causes regression of type 1 gastric neuroendocrine tumours in a nonrandomised trial of patients with chronic atrophic gastritis. PLoS One 8(10): e76462

47. Bass BP, Engel KB, Greytak SR, Moore HM (2014) A review of preanalytical factors affecting molecular, protein, and morphological analysis of formalin-fixed, paraffin-embedded (FFPE) tissue: how well do you know your FFPE specimen? Arch Pathol Lab Med 138(11):1520-1530

48. Sandvik AK, Waldum HL, Kleveland PM, Schulze Sognen B (1987) Gastrin produces an immediate and dose-dependent histamine release preceding acid secretion in the totally isolated, vascularly perfused rat stomach. Scand J Gastroenterol 22(7): 803-808

49. Sandvik AK, Waldum HL (1991) CCK-B (gastrin) receptor regulates gastric histamine release and acid secretion. Am J Phys 260(6 Pt 1):G925-G928

50. Prinz C, Scott DR, Hurwitz D, Helander HF, Sachs G (1994) Gastrin effects on isolated rat enterochromaffin-like cells in primary culture. Am J Phys 267(4 Pt 1):G663-G675

51. Nakata H, Matsui T, Ito M, Taniguchi T, Naribayashi Y, Arima N, Nakamura A, Kinoshita Y, Chihara K, Hosoda S et al (1992) Cloning and characterization of gastrin receptor from ECL carcinoid tumor of Mastomys natalensis. Biochem Biophys Res Commun 187(2):1151-1157

52. Håkanson R, Lilja B, Owman C (1969) Cellular localization of histamine and monoamines in the gastric mucosa of man. Histochem Cell Biol 18(1):74-86
53. Black J, Duncan W, Durant CJ, Ganellin CR, Parsons E (1972) Definition and antagonism of histamine H2-receptors. Nature 236: 385-390

54. BERGLINDH T, Helander HF, ÖBrink KJ (1976) Effects of secretagogues on oxygen consumption, aminopyrine accumulation and morphology in isolated gastric glands. Acta Physiol 97(4):401-414

55. Soll AH (1980) Secretagogue stimulation of [14C] aminopyrine accumulation by isolated canine parietal cells. Am J Physiol Gastrointest Liver Physiol 238(4):G366-G375

56. Brenna E, Waldum HL (1991) Studies of isolated parietal and enterochromaffin-like cells from the rat. Scand J Gastroenterol 26(12):1295-1306

57. Prinz C, Kajimura M, Scott DR, Mercier F, Helander HF, Sachs G (1993) Histamine secretion from rat enterochromaffinlike cells. Gastroenterology 105(2):449-461

58. Waldum H, Sandvik A, Brenna E, Walsh J (1993) Gastrin: histamine-releasing activity. Raven Press, New York

59. Athmann C, Zeng N, Scott DR, Sachs G (2000) Regulation of parietal cell calcium signaling in gastric glands. Am J Physiol Gastrointest Liver Physiol 279(5):G1048-G1058

60. Rangachari P, McWade D (1989) An "epithelial” preparation from the canine gastric mucosa: responses to secretagogues. Am J Physiol Gastrointest Liver Physiol 257(1):G46-G51

61. Bakke I, Qvigstad G, Brenna E, Sandvik AK, Waldum HL (2000) Gastrin has a specific proliferative effect on the rat enterochromaffin-like cell, but not on the parietal cell: a study by elutriation centrifugation. Acta Physiol Scand 169(1):29-37. https://doi.org/10.1046/j.1365-201x.2000.00688.x

62. Fukui H, Kinoshita Y, Maekawa T, Okada A, Waki S, Hassan MS, Okamoto H, Chiba T (1998) Regenerating gene protein may mediate gastric mucosal proliferation induced by hypergastrinemia in rats. Gastroenterology 115(6): 1483-1493

63. Bakke I, Qvigstad G, Sandvik AK, Waldum HL (2001) The CCK-2 receptor is located on the ECL cell, but not on the parietal cell. Scand J Gastroenterol 36(11):1128-1133

64. Tarasova NI, Romanov VI, Da Silva PP, Michejda CJ (1996) Numerous cell targets for gastrin in the guinea pig stomach revealed by gastrin/CCKB receptor localization. Cell Tissue Res 283(1):1-6

65. Tommeras K, Hammer P, Sundler F, Borch K, Mardh S, Cabero JL (2002) Immunolocalization of cholecystokinin-2 receptors in rat gastric mucosa. Scand J Gastroenterol 37(9):1017-1024

66. Helander HF, Wong H, Poorkhalkali N, Walsh JH (1997) Immunohistochemical localization of gastrin/CCK-B receptors in the dog and guinea-pig stomach. Acta Physiol Scand 159(4):313320. https://doi.org/10.1046/j.1365-201X.1997.114360000.x

67. Goetze JP, Eiland S, Svendsen LB, Vainer B, Hannibal J, Rehfeld JF (2013) Characterization of gastrins and their receptor in solid human gastric adenocarcinomas. Scand J Gastroenterol 48(6): 688-695 